\title{
Recreational Use of Acidic Pit Lakes-Human Health Considerations for Post Closure Planning
}

\author{
A. L. Hinwood ${ }^{1}$, Jane Heyworth ${ }^{2 *}$, Helen Tanner ${ }^{1}$, Clint McCullough ${ }^{1}$ \\ ${ }^{1}$ Centre for Ecosystem management, Edith Cowan University, Perth, Australia \\ ${ }^{2}$ Population Health, University of Western Australia, Perth, Australia \\ Email: ${ }^{*}$ jane.heyworth@uwa.edu.au
}

Received August 7, 2012; revised October 1, 2012; accepted October 15, 2012

\begin{abstract}
Pit lakes may form in mining voids that extend below groundwater level after mining ceases and many have been found to have elevated metals concentrations and low $\mathrm{pH}$ through acidic and metalliferous drainage (AMD). Pit lakes are often used for recreational activities including swimming, fishing and boating and poor water quality may present health risks to recreational users. Pit lakes also provide the opportunity for additional water resource uses. The Collie Coal Basin in south-western Australia currently has a number of pit lakes with moderate AMD effects which are also used for recreational pursuits. Twelve hundred questionnaires were mailed to selected addresses in the Collie shire with an additional 170 questionnaires to specific interest groups. Participants were asked about the type of activity, frequency and duration and any health symptoms experienced after use of the lakes. Two hundred and fifty questionnaires were returned, which comprised 176 returns from the random sample and 74 from the targeted sample. Three pit lakes with elevated metals concentrations and low $\mathrm{pH}$ were used for recreational purposes by $62 \%$ of respondents. This was mostly in summer with swimming the most common activity. Of all respondents $52 \%$ were concerned about lake water quality and 38\% using the lakes reported a variety of symptoms. Recreational use of Collie pit lakes did not represent a health risk for most of the surveyed population due to the low frequency and duration of use, however health risks may be elevated in sensitive users such as children and those consuming seafood from the lakes. Comprehensive water quality monitoring for chemicals and further characterisation of recreational use of pit lakes is warranted to more comprehensively assess the potential health risks to recreational users. Post closure mine plans need to consider potential future community uses combined with assessments of water quality and physical characteristics to reduce the potential for adverse health and safety impacts.
\end{abstract}

Keywords: Pit Lake; Acidity; Metals; Recreational Use; Health Impacts; Management

\section{Background}

Open cut mining has left a legacy of many thousands of mining pit voids worldwide with increasing frequency and scale [1-4]. Pit lakes are formed in mine voids once extractive and dewatering operations have ceased and water has accumulated through surface and groundwater inflows [3,5]. The water quality of pit lakes is variable and is an aspect determined by the geology of the void, water inflow quality, groundwater quality and surrounding activities and land uses including the presence of waste rock [6,7]. Water quality of coal pit lakes is often poor as a result of low $\mathrm{pH}$ and elevated metals concentrations caused by acidic and metalliferous drainage (AMD) resulting from weathering of sulphidic minerals such as pyrite [6]. Metals is the term being used in this paper to describe heavy metals, metalloids and transitional metals.

Following mine closure, closure plans are imple-

${ }^{*}$ Corresponding author. mented to minimise environmental harm and address potential social impacts by providing for a geotechnically stable and safe mine void $[8,9]$. Future use of the pit lakes by the community has largely been ignored in the planning process. Over the past ten years the international mining industry and regulators have increasingly considered the importance of the benefits of pit lakes as additional community water resources and there has been some recognition that pit lakes may have potential beneficial end uses that could contribute economic, health, welfare, safety or aesthetic benefits assuming a degree of remediation and management $[7,10]$. Activities such as tourism (swimming, fishing and boating), wildlife conservation and irrigation water for agriculture and horticulture have been highlighted as possible beneficial end uses $[7,10]$.

The physico-chemical characteristics as well as geotechnical aspects can influence the future use of pit lakes. 
Features such as the steep walls associated with the mining process and depth need to be considered where community use is an option. Clarity is another important characteristic of lakes and is influenced by microscopic plants and animals, suspended particles and dissolved substances such as iron [11]. There are also a range of organisms that can survive in acidic pit lakes and hence present risks to users [12]. The potential for microorganisms to cause an adverse health impact is dependent on the pathogen, its form, the conditions of exposure, the hosts susceptibility and immune status [13]. Water bodies used for recreational purposes are likely to contain faecal matter that may be harmful to health. E coli is tolerant of acidic conditions. Crypotsporidium and Giardia spp. are faecally derived protozoa that can survive for significant durations outside their host organisms. It is not known at this time whether these species exist in pit lakes, however much has been written about these pathogens in terms of recreational water bodies [14].

Activities around pit lakes such as walking and camping may also increase risks in terms of injury due to the distinct physical aspects. Pit lakes, particularly in hard rock areas, can have steep sides and great depth making it easy for waders and swimmers to get out of depth and experience difficulties getting out of water. Poor clarity of the water and strong colour stains may also make the depth of the water difficult to assess [11].

Limited research has been undertaken to assess the risks of health effects from recreational activities undertaken at pit lakes. Doupe and Lymbery [7] ranked the risks of recreation and tourism of pit lakes as high when considering a variety of beneficial uses. Many authors have commented on the biological quality of surface water bodies and the potential health risks associated with recreational use $[15,16]$. There has been little focus on the chemical water quality of pit lakes and risks of human exposure to low $\mathrm{pH}$ and elevated metals concentrations for recreational users. This is compounded by little information on the types, frequency and duration of activities in pit lakes to inform health risk assessment.

The Collie region of south-western Australia currently has 13 mine pit lakes with two public lakes used regularly for recreational activities [17]. The water quality of pit lakes in Collie varies with some high concentrations of metals recorded and low $\mathrm{pH}(4.0$ - 5.5) [18,19].

Our study aimed to describe the recreational use of the Collie pit lakes and from this assess the likelihood of exposure to elevated metals concentrations and low $\mathrm{pH}$. This assessment of the potential for health impacts would hence inform management of pit lakes for recreational use.

\section{Materials and Methods}

A cross sectional questionnaire survey was conducted of recreational use of pit lakes in residents in the Collie Shire, south-western Australia. This was combined with a review of available surface water quality data for the lakes. The study received ethics approval from the ECU Human Research Ethics Committee 2009.

\subsection{Study Area}

Collie is located in the South Western region of Western Australia and has a Mediterranean climate consisting of cool winters and hot dry summers. Coal has been mined in the Collie area since 1888, with coal used predominantly for generation of electricity [20]. Discontinued mine voids have been present in the area for approximately 50 years [20].

Situated in the Collie Coal Basin, the town of Collie experiences higher rainfall than many other areas of the state with average rainfall of $932 \mathrm{~mm}$ (Commonwealth of Australia Bureau of Meteorology, 06/08/2011). The majority of mines in the area are open-cut mines below the ground water table, resulting in pit lakes at closure [21]. Currently two lakes, Stockton and Black Diamond, are used by the public for recreational activities (Figure 1). Nearby Lake Kepwari is also being considered as a recreational area although it was not open to the public. Nevertheless, although the lease holding mining company has attempted to prevent access, many people still use the lake.

\subsection{Study Population}

The study population was residents living within the Shire of Collie, a population of 9104 people [22]. We determined that 264 responses were required to estimate the prevalence of recreational use with a $90 \%$ confidence level and an Type 1 error of 5\%.

\subsection{Study Recruitment}

Two methods were used to recruit participants; a random postal survey of Collie Shire residents and a targeted survey. A mailing list of 1300 postal addresses in the Collie Shire (postcode 6225) was randomly selected from the 2004 White Pages phone directory by the Edith Cowan University Survey Research Centre. Towns in this postcode included Collie, Allanson, Buckingham, Collie Burn, Noggerup, and McAlinder. An information package was prepared and posted to 1200 households from the mailing list. An additional 100 addresses were available for mail-out where there were no householders at the current address. The package included a letter of invitation to participate, the questionnaire, an information sheet and a reply-paid envelope for questionnaire return. One person from each household was asked to answer the questionnaire about their individual use of the pit lakes. 


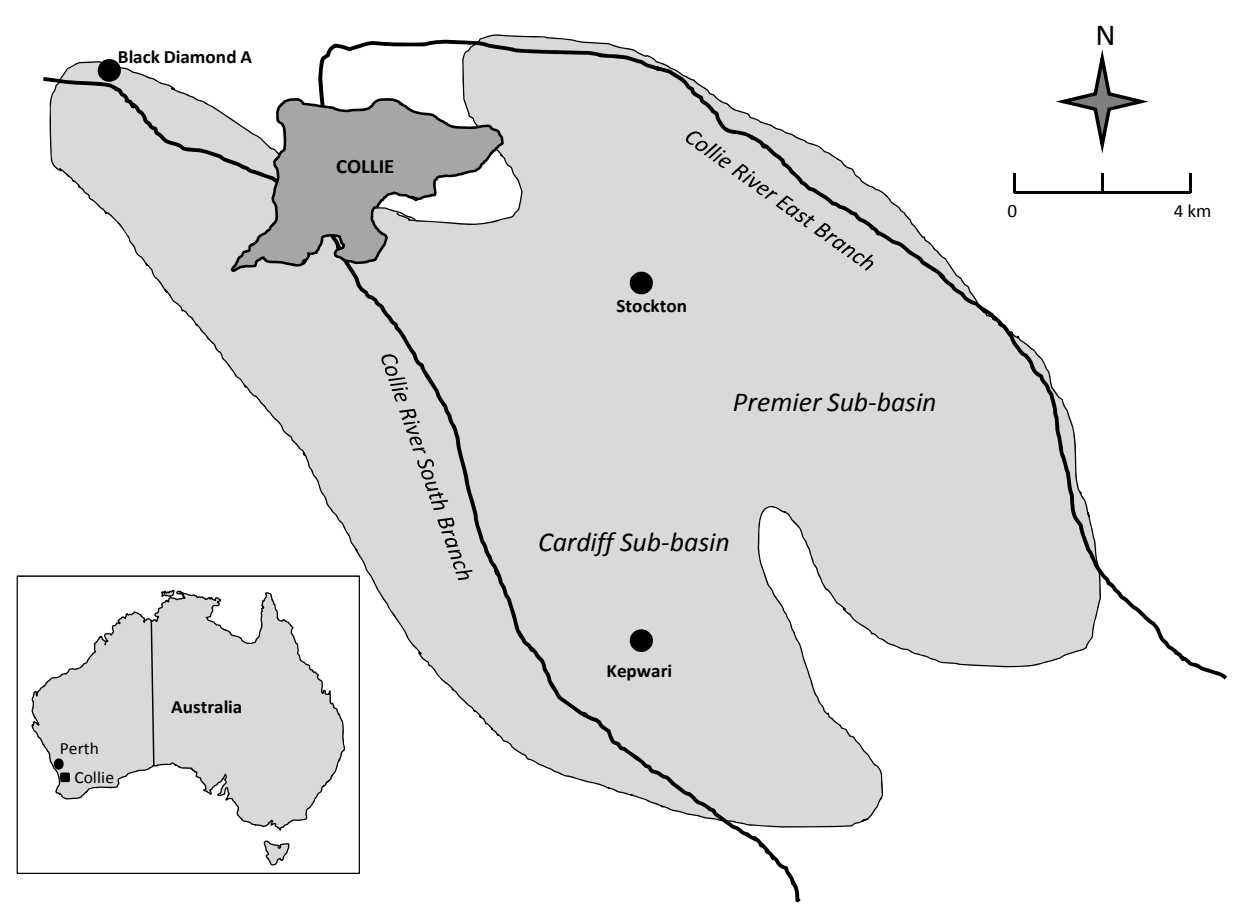

Figure 1. Location of study area and pit lakes.

A second recruitment stage took place with 40 information packages sent to special interest groups. Member names from these groups were supplied by the Western Australian Government Department of Water. Copies of the questionnaire were also made available at the local council and library. Reply paid envelopes were left at both locations for return of questionnaires. An information booth was also set up at the local shopping centre to recruit more participants and to provide background information about the study. The researchers targeted people at the local shopping centre over a two day period in November 2009 asking them to complete a questionnaire. Respondents to the questionnaire needed to be over 18 years of age.

\subsection{Data Collection-Questionnaire}

The questionnaire addressed use at the three most popular lakes. Questions included time spent by respondents and their families using one or more pit lakes for recreation, time spent in contact with lake water and what type of activities they undertook. Respondents were also asked about: any health symptoms they experienced following use of the lakes; their views on management of the lakes; and the uses that should be permitted.

Questionnaires were coded distinguishing between the random sample and the targeted population. In total 250 questionnaires were available for analysis. From the randomly selected group 176 questionnaires were obtained from 1095 delivered (105 were returned to send- er), giving a response fraction of $16 \%$. Another 74 (44\%) questionnaires were received from the 170 distributed to the targeted audience.

\subsection{Data Management and Analysis}

All data was entered into a Microsoft access database and double entered. The data were checked for accuracy and cleaned. Descriptive statistical analyses were performed using SPSS version 17.0 Responses from the random and targeted sample groups were similar for all study variables except for the proportion who used the lakes. For the randomly selected group 58\% used the lakes in the past two years, whereas $69 \%$ of the target group had used the lakes. Consequently, responses from the combined group are presented in relation to the lake activities among users.

Swimming, wading and water skiing were classified into a single category to determine time spent undertaking water based activities. When calculating the average time spent undertaking each activity, variables with more than 12 hours (three questionnaires) were not used as it was deemed unlikely that an individual would spend over this amount of time per visit undertaking one activity (excluding camping). The total amount of time spent undertaking water based activities was calculated for each lake by summing the amount of time taken for each activity together. An average was then taken of all respondents who had spent time undertaking water based activities. 


\section{Results}

\subsection{Population Characteristics}

The population surveyed was predominantly male and older with a mean age of 56 years (Table 1). Both males and females used the pit lakes with a slightly higher percentage of males using the lakes for recreational purposes. One hundred and fifty four people indicated they had used the pit lakes in the last two years. Respondents visited Black Diamond and Stockton Lakes for a median of two days per month and most visitors spent time at both lakes (Tables 1 and 2). The number of children who visited the lakes was small with only $23 \%$ of children under 12 years of age. Not surprisingly, visits to lakes were highest in spring/summer and lowest in autumn/winter (Figure 2). The majority of adults who attended the lakes visited in the afternoon and spent on average between 3 to 5.5 hours in water based activities (Table 3).

\subsection{Types of Activities Undertaken at the Lakes}

Swimming was the most popular water based recreation amongst adults for each of the lakes (Table 4). Among participants who used the lakes, the highest percentage of participants swimming was at Black Diamond. Boating and water skiing were undertaken more often at Stockton Lake than the other lakes. Of the non water-based activeties, picnicking at Stockton Lake was the most common activity (Table 4).

The types of activities undertaken at each lake did not differ by sex except at Lake Kepwari where men undertook all of the listed activities whereas women undertake swimming, wading, boating and picnicking (data not reported).

Of the water based activities, more time was spent water skiing and boating (Table 4). Of those who went swimming, Stockton Lake had the highest average hours spent swimming. Respondents who used the pit lakes

Table 1. Demographic characteristics of respondents categorised by pit lake use.

\begin{tabular}{|c|c|c|c|}
\hline & $\begin{array}{l}\text { People who did not } \\
\text { use pit lakes }\end{array}$ & $\begin{array}{l}\text { People who used pit } \\
\text { lakes }\end{array}$ & Total population \\
\hline Total population $(\mathrm{n}=250)$ & $38.4 \%$ & $61.6 \%$ & \\
\hline Random population (\%) (n = 176) & $41.5 \%$ & $58.5 \%$ & $70.4 \%$ \\
\hline Targeted population (\%) $(\mathrm{n}=74)$ & $31.1 \%$ & $68.9 \%$ & $29.6 \%$ \\
\hline Median distance lived from lakes (km) (range ) & $10(0.5-65)$ & $8(0.4-80)$ & $10.6(0.4-80)$ \\
\hline Age mean (years) & 60 & 50 & 54 \\
\hline Range & $19-90$ & $18-82$ & $19-90$ \\
\hline (n) & (94) & (150) & \\
\hline Sex (Male \%) & $38.5 \%$ & $61.5 \%$ & $57.2 \%$ \\
\hline (n) & (143) & (143) & (143) \\
\hline \multicolumn{4}{|l|}{ Among those using the lakes } \\
\hline Household with children 13 - 18 years (\%) & - & $16.6 \%$ & \\
\hline Households with children < 12 years (\%) & - & $23.2 \%$ & \\
\hline
\end{tabular}

Table 2. Median number of days respondents visited each Collie pit lake, among those who used the pit lakes $(n=154)$.

\begin{tabular}{cccc}
\hline & Black Diamond & Kepwari & Stockton \\
\hline Median number days/month & 2 & $1-4$ & 2 \\
Range & $1-30$ & $(32)$ & $(115)$ \\
(n) & $(125)$ & 2.5 & 8.5 \\
Median number days/year & 10 & $1-20$ & $1-300$ \\
Range & $1-360$ & $(34)$ & $(115)$ \\
\hline
\end{tabular}




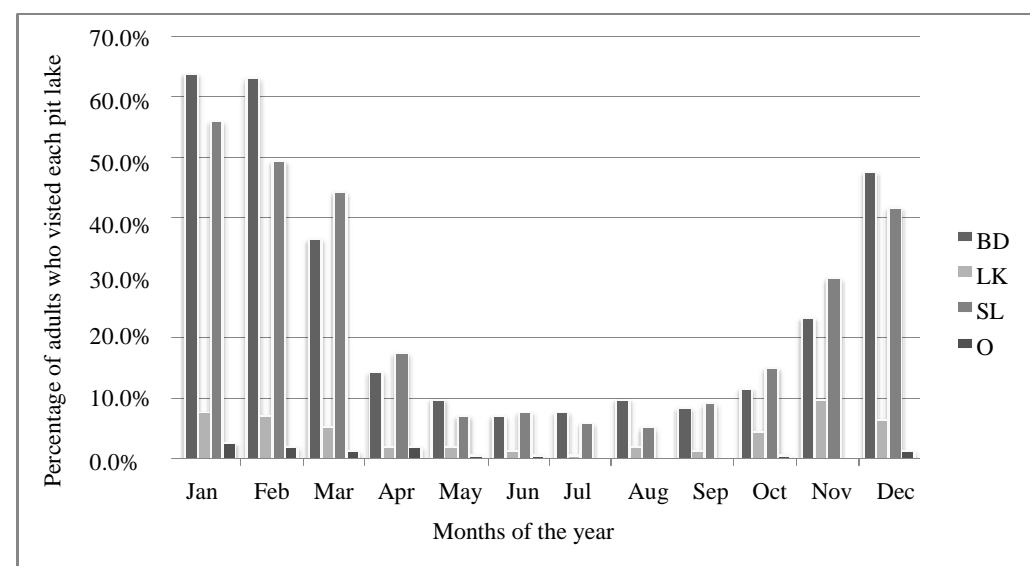

Figure 2. Distribution of respondent visits to lakes by month of year; BD: Black diamond; LK: Lake kepwari; SL: Stockton lake; O: Other lakes.

Table 3. Reported time of day respondents most likely to visit the pit lakes $\left(n=154^{*}\right)$.

\begin{tabular}{ccc}
\hline $\begin{array}{c}\text { Time most likely } \\
\text { to use pit lakes }\end{array}$ & Percentage (\%) & $\begin{array}{c}\text { Average time of } \\
\text { water-based activities (h) }\end{array}$ \\
\hline All Day & 21.5 & 5.4 \\
Morning & 8.1 & 5.5 \\
Afternoon & 65.8 & 3.3 \\
Dusk & 3.3 & 3 \\
Night & 1.3 & 0 \\
\hline
\end{tabular}

*Data missing for 5 respondents.

for camping spent most time at Stockton Lake (Table 4). The range of responses given for the amount of time taken when undertaking each activity varied greatly and also varied between the lakes. Across the lakes and activities, respondents spent on average 2 hours undertaking water based activities.

The number of people who indicated they ate seafood (freshwater crayfish marron Parastacidae: Cherax tenuimanus) caught from the pit lakes was higher than the number of respondents who said they went fishing. Forty two respondents said they ate seafood caught from the pit lakes (data not shown). Of the people who went marroning $90 \%(\mathrm{n}=31)$ ate their catch and of the respondents who said they did not go marroning 13 indicated they ate seafood which was caught from the pit lakes.

\subsection{Self Reported Health Effects}

From a list of health symptoms, respondents were asked whether they experienced any after using the pit lakes. Health symptoms were reported by $38 \%$ of participants (Table 5). The most common symptom experienced by
Table 4. Percentage of respondents reporting recreational activities and time spent on these activities at each Collie pit lake (\%).

\begin{tabular}{cccc}
\hline & $\begin{array}{c}\text { Black } \\
\text { Diamond } \\
(\mathrm{n}=127)\end{array}$ & $\begin{array}{c}\text { Lake } \\
\text { Kepwari } \\
(\mathrm{n}=32)\end{array}$ & $\begin{array}{c}\text { Stockton } \\
\text { Lake } \\
(\mathrm{n}=123)\end{array}$ \\
\hline Swimming \% & $83.5 \%$ & 53.1 & 72.4 \\
Mean Hours & 2.6 & 2.5 & 2.9 \\
(range) & $0.5-12$ & $1-6$ & $0.5-12$ \\
Kayaking/Canoeing \% & 15.0 & 3.1 & 15.4 \\
Mean Hours & 1.7 & 1.0 & 2.8 \\
(range) & $0.5-4$ & 1 & $0.5-10$ \\
Wading \% & 31.5 & 21.9 & 24.4 \\
Mean hours & 2.2 & 1.2 & 2.5 \\
(range) & $0.5-10$ & $1-2$ & $0.5-10$ \\
Boating \% & 6.3 & 9.4 & 40.7 \\
Mean hours & 3.0 & 1.6 & 3.7 \\
(range) & $1-5$ & $1-2$ & $0.5-12$ \\
Water skiing \% & 2.4 & 3.1 & 27.6 \\
Mean Hours & 4.3 & 2.0 & 4.4 \\
(range) & $4-5$ & 2 & $2-12$ \\
Fishing (marroning) \% & 11.0 & 9.4 & 12.2 \\
Mean hours & 3.3 & $\mathrm{n} / \mathrm{a}$ & 4.0 \\
(Range) & $1-6$ & & $2-6$ \\
Picnicking \% & 42.5 & 40.6 & 47.2 \\
Camping \% & 20.5 & 9.4 & 30.9 \\
Walking \% & 7.9 & 9.4 & 2.4 \\
Other \% & 7.1 & 28.1 & 11.4 \\
\hline
\end{tabular}


Table 5. Percentage of respondents who reported health symptoms after visiting the pit lakes.

\begin{tabular}{|c|c|c|c|c|c|c|}
\hline & \multicolumn{2}{|c|}{ Never } & \multicolumn{2}{|c|}{ Sometimes } & \multicolumn{2}{|c|}{ Most times } \\
\hline & $\begin{array}{l}\text { Adult (\%) } \\
(\mathrm{n}=140)\end{array}$ & $\begin{array}{l}\text { Children (\%) } \\
\quad(\mathrm{n}=32)\end{array}$ & $\begin{array}{l}\text { Adult (\%) } \\
(\mathrm{n}=140)\end{array}$ & $\begin{array}{l}\text { Children (\%) } \\
\quad(\mathrm{n}=32)\end{array}$ & $\begin{array}{c}\text { Adult (\%) } \\
(\mathrm{n}=140)\end{array}$ & $\begin{array}{c}\text { Children (\%) } \\
\quad(\mathrm{n}=32)\end{array}$ \\
\hline Skin rashes/irritation & 91 & 94 & 7 & 6 & 2 & 0 \\
\hline Sore Eyes & 78 & 81 & 19 & 19 & 4 & 0 \\
\hline Feeling sick & 98 & 100 & 2 & 0 & 0 & 0 \\
\hline Vomiting & 100 & 97 & 0 & 3 & 0 & 0 \\
\hline Diarrhoea & 99 & 100 & 1 & 0 & 0 & 0 \\
\hline Runny nose & 90 & 91 & 8 & 9 & 2 & 0 \\
\hline Headaches & 91 & 94 & 7 & 6 & 1 & 0 \\
\hline Feeling tired & 91 & 91 & 8 & 9 & 1 & 0 \\
\hline Temperature & 97 & 100 & 2 & 0 & 1 & 0 \\
\hline Sore throat & 91 & 94 & 7 & 6 & 2 & 0 \\
\hline Other & 99 & 97 & 0 & 0 & 1 & 3 \\
\hline
\end{tabular}

adults was sore eyes with $19 \%$ experiencing this sometimes, and 4\% experiencing sore eyes most times they undertook recreational activity at the lakes (Table 5). Skin irritations/rashes, runny noses, headaches, sore throats and feeling tired were other symptoms experienced (Table 5).

The most common health symptoms reported for children under12 yrs old was sore eyes. Other health effects reported included feeling tired, runny nose, skin rash, headaches or sore throat (Table 5). Males experienced more symptoms than women reporting 9 out of the 11 symptoms and males reported having sore eyes more often than females whereas females experienced headaches more often than males (data not shown). When assessed by specific lake, more respondents reported symptoms when visiting Black Diamond compared with Stockton but the numbers were too small for analysis (data not shown).

A comparison was made of the total amount of time spent undertaking water based activities and the symptoms respondents reported (Figure 3) where more were reported if they spent over 10 hours undertaking waterbased activities (Figure 3 ).

\subsection{Water Quality Data}

Limited surface water quality monitoring has been undertaken at the Collie Pit Lakes and available data for two lakes most commonly used for recreational activities is shown in Table 6 and available guideline values for selected metals and $\mathrm{pH}$ are also shown.

Typical of many coal geologies, Collie coal has pyrite associated with the basin's coal. Although Collie geol- ogies are of low sulphur content, following exposure and weathering, acidity is produced from oxidation, ferrolysis and secondary mineralization [18]. $\mathrm{pH}$ of between 3.8 and 6.8 (averaging 4 - 5) have been recorded at three lakes used for recreational purposes (Table 6). The three year average $\mathrm{pH}$ meets the recreational water guidelines however individual samples do not meet the guidelines (Table 6). The metals concentrations are difficult to interpret as there are limited samples and many of the detection limits are higher than guideline values.

Aluminium concentrations at Stockton Lake were above both the Australian Drinking Water Guidelines [23] and recreational water guidelines [24] (Table 6). Arsenic concentrations were also elevated and some samples exceeded both recreational and drinking water guidelines. The few samples at Black Diamond were at the limit of detection. At Stockton Lake, cadmium concentrations were generally above detection limits with one sample at the recreational water quality guideline level. Iron concentrations at Black Diamond and Stockton Lake did not exceed the drinking water [23] or recreational water guidelines [24] but again individual samples did. The detection limits for lead were also above guideline values. Mercury concentrations at Black Diamond were high and well above guideline values (Table 6). Interpretation of mercury concentrations at Stockton Lake were influenced by detection limits which were higher than the relevant guideline values $[23,24]$.

The pit lakes exceeded drinking water guidelines for nickel [23] but not recreational water quality. Boron, chromium, copper and zinc concentrations were well below drinking water and recreational water guidelines and are not reported here. 


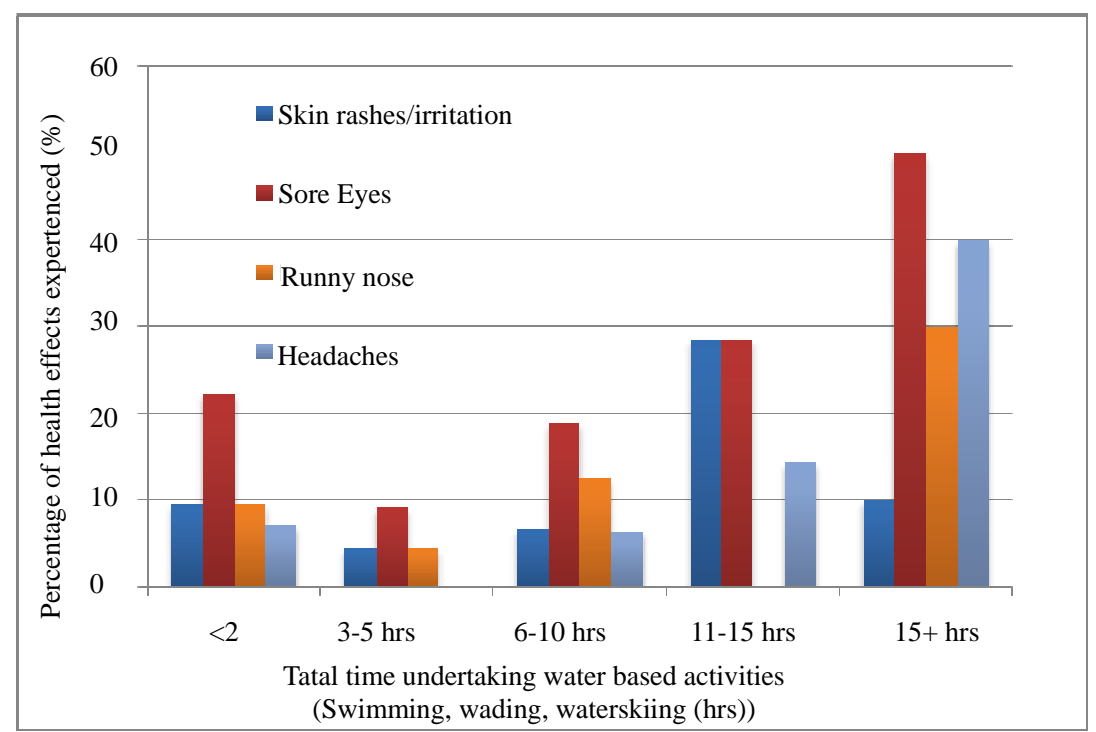

Figure 3. Percentage of health effects by the amount of time spent undertaking water based activities.

Table 6. Three year mean surface water metal concentrations and $\mathrm{pH}$ at the Collie Pit lakes ( $\mu \mathrm{g} / \mathrm{L})$ (McCullough et al., 2010).

\begin{tabular}{|c|c|c|c|c|c|}
\hline & & Black Diamond & Stockton & $\mathrm{ADWG}^{*}$ & $\mathrm{RWG}^{*}$ \\
\hline & Mean & $<$ DL (100) & 529 & 7 & 50 \\
\hline \multirow[t]{3}{*}{ Aluminium } & Range & $<\mathrm{DL}$ & $23-1800$ & & \\
\hline & $\mathrm{n}$ & 2 & 27 & & \\
\hline & Mean & 37.5 & 15.2 & 7 & 50 \\
\hline \multirow[t]{3}{*}{ Arsenic } & Range & $<\mathrm{DL}-50$ & $0.5-64$ & & \\
\hline & $\mathrm{n}$ & 2 & 22 & & \\
\hline & Mean & $<\mathrm{DL}(10)$ & 1.4 & 2 & 5 \\
\hline \multirow[t]{3}{*}{ Cadmium } & Range & $<\mathrm{DL}$ & $0.05-5$ & & \\
\hline & $\mathrm{n}$ & 2 & 21 & & \\
\hline & Mean & 51.5 & 121.8 & 200 & 200 \\
\hline \multirow[t]{3}{*}{ Iron } & Range & $<\mathrm{DL}-53$ & $5-310$ & & \\
\hline & $\mathrm{n}$ & 2 & 23 & & \\
\hline & Mean & <DL (100) & 11.4 & 10 & 50 \\
\hline \multirow[t]{3}{*}{ Lead } & Range & $<\mathrm{DL}$ & $0.5-25$ & & \\
\hline & $\mathrm{n}$ & 1 & 5 & & \\
\hline & Mean & 134 & 58.2 (3 yr) & 300 & 300 \\
\hline \multirow[t]{3}{*}{ Manganese } & Range & $51-217$ & $5-140$ & & \\
\hline & $\mathrm{n}$ & 2 & 26 & & \\
\hline & Mean & 170 & 27.5 & 1 & 1 \\
\hline \multirow[t]{3}{*}{ Mercury } & Range & $100-241$ & $5-50$ & & \\
\hline & $\mathrm{n}$ & 2 & 2 & & \\
\hline & Mean & 37.5 & 47.7 & 100 & 100 \\
\hline \multirow[t]{2}{*}{ Nickel } & Range & $33-42$ & $20-81$ & & \\
\hline & $\mathrm{n}$ & 2 & 3 & & \\
\hline \multirow[t]{3}{*}{$\mathrm{pH}$} & 3y Av & 5.5 & 4.9 & $6.5-8.5$ & $5.0-9.0$ \\
\hline & Range & $4.4-6.8$ & $3.8-6.3$ & & \\
\hline & $\mathrm{n}$ & (3) & (20) & & \\
\hline
\end{tabular}

*Australian Drinking Water Guidelines (NHMRC/NRMMC (2004); ${ }^{* *}$ Australian and New Zealand Guidelines for Fresh and Marine Water Quality (Ch. 5 Recreational water) (2000); $<\mathrm{DL}=$ Below Detection Limit. 


\subsection{Physical Characteristics of the Lakes}

The pit lakes range from $<1$ ha up to 10 ha in surface area with depths ranging from $<10 \mathrm{~m}$ up to $70 \mathrm{~m}$ [17]. Most have beaches enabling easy access by members of the community, although in some parts of the lake, the characteristic steep sides can be observed.

The clarity of the pit lakes in Collie has been measured using Secchi depth in four lakes [19]. Black Diamond recorded a mean Secchi depth of $3.3 \mathrm{~m}+/-0.3 \mathrm{~m}$, Blue Waters recorded $4.1 \mathrm{~m} \mathrm{+/}-0.3 \mathrm{~m}$, Ewington $3.8 \mathrm{~m} \mathrm{+/-}$ $0.3 \mathrm{~m}$ and Lake Stockton recorded a mean Secchi depth of $3.8 \mathrm{~m}+/-0.4 \mathrm{~m}$ [24]. A Secchi depth to $1.6 \mathrm{~m}$ is sufficient for water bodies used for swimming [24]. The lakes exhibit different temperatures at different times of year. Lund \& McCullough (2008) [18] state the lakes in the Collie region are monomictic and are thermally stratified between November and March each year, however water temperature were not stated for the individual lakes [18]. In spring, water temperatures ranged from approximately $16^{\circ} \mathrm{C}$ to $20^{\circ} \mathrm{C}$. In summer, temperatures ranged from approximately $20^{\circ} \mathrm{C}$ to $25^{\circ} \mathrm{C}$ [19].

\section{Discussion}

The Collie Pit Lakes had variable water quality including $\mathrm{pH}$. Clarity and temperature of the lakes were within acceptable ranges for recreational pursuits. For the two most commonly visited lakes in the Collie area, there were few surface water quality data available and of the data that were available, some individual sample concentrations of mercury, arsenic, manganese and aluminium exceeded recreational water quality guidelines and a few samples exceed drinking water guidelines. $\mathrm{pH}$ was considered low.

There was a high level of recreational use of the Collie pit lakes among respondents to the survey. As would be expected use is high in the warmer months of the year. Families, the elderly and the young use the pit lakes for water-based activities, particularly swimming. The lakes were popular locations for picnicking and boating. Another popular activity was camping. A small number of people reported fishing for crustacea and consuming the seafood caught from the lakes.

It is acknowledged that it is difficult to estimate the true population use of the lakes due to the high non-response to this survey. However we expect that users of the lakes were more likely to respond. For users of the lakes there is no reason to believe that the response of the participants regarding the nature of the use differ from non-responding users of lakes. It is likely that non users were a greater proportion in the non-responders, however, among the users of the lakes these data provide reasonable estimates of the nature of the use. A greater response to the questionnaire would have given a better represen- tation of the recreational habits of the Collie community and visitors from other regions at the pit lakes.

Health effects were reported by $38 \%$ of respondents who visited the lakes. Visitors to Black Diamond and Stockton Lake reported experiencing the most health effects and the most common heath effect experienced by both adults (22.3\%) and children (18.8\%) was sore eyes followed by reports of skin irritations and rashes. There was some suggestion of increasing symptoms with more than $10 \mathrm{~h}$ of water related activities however there were low numbers of respondents undertaking more than 10 hours of activity. We cannot draw conclusions about nonspecific symptoms that may result from water related use of pit lakes because of potential for selection bias and the cross-sectional design. Participants who responded may have done because they had experienced health effects and thus were more interested in the study. However, these data suggest that sore eyes may warrant further investigation.

The recommended Australasian recreational guideline $\mathrm{pH}$ for primary contact activities such as swimming is 5 to 9 [24]. Low pH can also remove outer skin layers increasing susceptibility to absorption of chemicals [26]. Previous research has shown that $\mathrm{pH}$ below 5 can result in both eye and skin irritation [11]. The $\mathrm{pH}$ at both Stockton and Black Diamond lakes were low and could result in some skin irritation in recreational users [25]. $\mathrm{pH}$ therefore, presents a risk for skin and eye irritation for those with direct contact with the water and those with conditions that may be exacerbated by low $\mathrm{pH}$. These results provide some indication of the potential for adverse symptoms. However, they are based upon self reports and may be the result of other exposures occurring at the same time.

While high concentrations of metals in drinking water have been associated with many health effects, the results of this survey suggest there are only low levels of risk to health from exposure to elevated metals concentrations in the pit lakes as a result of low frequency and duration of use. These concentrations could present a risk to vulnerable groups and in particular children who are likely to be at a higher risk of adverse health effects due to their developing status and potential for higher metal intakes [25]. Another group at increased risk are those consuming seafood as crustaceans which are known to accumulate metals [26] and therefore could introduce an additional exposure source.

There is clearly a need to better define the concentrations of metals in these pit lakes and the contribution of additional sources of exposure such as seafood. In addition, from a human health perspective while surface water samples are relevant, the knowledge gained from understanding of processes in pit lakes is vital to account for changes in water quality over time. For example con- 
centrations could be higher where turnover occurs in pit lakes. This will also require regular targeted monitoring of the pit lakes. Given the lack of monitoring to aid decision making, managers need to consider recreational use and monitor water quality to determine seasonal and spatial variation with detection limits below current guideline values. Caution should therefore be exercised by organisations managing these areas in terms of advice on the potential health impacts for users and additional data should be collected to enable an appropriate assessment of risk.

The potential exists for a variety of human uses of pit lakes where water is increasingly becoming an expensive and scarce commodity. In addition, the growth of communities in regional areas makes it likely recreational opportunities from pit lakes will be pursued. Because each pit lake is likely to vary in its physical characteristics and physico-chemical processes, it is essential that managers consider post closure uses that may include recreational or human use of the water for other purposes such as aquaculture.

There is limited literature on the potential for health effects from recreational use of pit lakes and because each pit lakes varies in its physical, chemical and biological characteristics, individual lakes need to be considered in terms of its use and the potential for human health impacts. In some circumstances the physicochemical characteristics may reduce biological activity in a water body therefore reducing risks to recreational users however recreational use may introduce faecal coliforms and other organisms presenting significant risks which managers need to consider.

It is therefore recommended that in the development of post closure mine plans, the potential for human use be identified and where this is likely, criteria reflecting exposure sources, pathways and activities, water quality objectives and recreational criteria pertaining to safety be established. The approach could be modelled on the way contaminated sites is viewed in terms of future beneficial use and relevant criteria for remediation. This would occur alongside issues of stability and structural integrity affecting the potential for injury from physical risks.

It is also recommended that managers of areas where pit lakes are currently used for recreational purposes undertake monitoring and evaluation of each lake in relation to the factors outlined above and target appropriate parameters and detection limits.

\section{Concluding Remarks}

This study has shown that recreational use of pit lakes may be more common than previously thought. Recreational use of Collie pit lakes did not represent a health risk for most of the surveyed population due to the low frequency and duration of use. However health risks may be elevated in sensitive users such as children and those consuming seafood from the lakes. Human health risks will differ depending on the recreational activity, nature and intensity and water quality of lakes. Comprehensive water quality monitoring for chemicals and further characterisation of recreational use of pit lakes is warranted to more comprehensively assess the potential health risks to recreational users.

Post mining pit lakes often represent an important regional recreational resource and consideration of both water quality and physical characteristics are required to reduce impacts to health and safety. Hence post closure mining plans should include consideration of future community uses combined with assessments of water quality and physical characteristics.

\section{Acknowledgements}

We would like to thank the community of Collie for responding to the Questionnaire. We would also like to thank DOW staff for their assistance in providing information on contacts in the region and distributing the questionnaire. This project was part funded by the Department of Water and the Australian Government's Water for the Future initiative.

\section{REFERENCES}

[1] H. Klapper and W. Geller, "Water Quality Management of Mining Lakes-A New Field of Applied Hydrobiology," Acta Hydrochimica et Hydrobiologica, Vol. 29, No. 6-7, 2002, pp. 363-374.

doi:10.1002/1521-401X(200112)29:6/7<363::AID-AHE H363>3.0.CO;2-E

[2] J. Crusius, R. Pieters, A. Leung, P. Whittle, G. Pedersen, G. Lawrence and J. J. McNee, "Tale of Two Pit Lakes: Initial Results of a Three Year Study of the Main Zone and Waterline Pit Lakes near Houston, British Columbia, Canada," Mining Engineering, Vol. 55, No. 2, 2003, pp. 43-48.

[3] K. A. Filippova and V. V. Deryagin, "Chemical Hydrology of Mine Pit Lakes of the Bakala Geotechnic System (Southern Urals),” Water Resources, Vol. 32, No. 4, 2005, pp. 427-433. doi:10.1007/s11268-005-0054-8

[4] C. D. McCullough, "Mine Pit Lakes: Closure and Management,” Australian Centre for Geomechanics (ACG), Perth, 2011, 183 p.

[5] J. M. Castro and J. N. Moore, "Pit Lakes: Their Characteristics and the Potential for Their Remediation," Environmental Geology, Vol. 39, No. 11, 2000, pp. 12541260. doi:10.1007/s002549900100

[6] G. E. Miller, W. B. Lyons and A. Davis, "Understanding the Water Quality of Pit Lakes,” Environmental Science and Technology, Vol. 30, No. 3, 1996, pp. 118A-123A. doi:10.1021/es9621354 
[7] R. G. Doupe and A. J. Lymbery, "Environmental Risks Associated with Beneficial End Uses of Mine Lakes in Southwestern Australia," Mine Water and the Environment, Vol. 24, No. 3, 2005, pp. 134-138. doi:10.1007/s10230-005-0084-0

[8] G. A. Doyle and D. D. Runnells, "Physical Limnology of Existing Mine Pit Lakes,” Minerals Engineering, Vol. 49, No. 12, 1997, pp. 76-80.

[9] S. L. Johnson and A. H. Wright, "Mine Void Water Resource Issues in Western Australia," Water and Rivers Commission, 2003, 93 p.

[10] C. D. McCullough and M. A. Lund, "Opportunities for Sustainable Mining Pit Lakes in Australia,” Mine Water and the Environment, Vol. 25, No. 4, 2006, pp. 220-226. doi:10.1007/s10230-006-0136-0

[11] World Health Organisation, "Guidelines for Safe Recreational Water Environments: Volume 1 Coastal and Freshwaters,” Wold Health Organization, Geneva, 2003.

[12] B, Nixdorf, A. Fyson and H. Krumbeck, "Review: Plant Life in Extremely Acidic Waters," Environmental and Experimental Botany, Vol. 46, No. 3, 2001, pp. 203-211. doi:10.1016/S0098-8472(01)00104-6

[13] National Health and Medical Research Council, "Guidelines for Managing Risks in Recreational Water," National Health and Medical Reseach Council, Australian Government, Canberra, 2008.

[14] S. Dorevitch, N. J. Ashbolt, C. M. Ferguson, R. Fujioka, C. D. McGee, J. A. Soller and R. L. Whitman, "Meeting Report: Knowledge and Gaps in Developing Microbial Criteria for Inland Recreational Waters,” Environmental Health Perspectives, Vol. 118, No. 6, 2010, pp. 871-876. doi:10.1289/ehp.0901627

[15] T. J. Wade, R. L. Calderon, E. Sams, M. Beach, K. P. Brenner, A. H. Williams and A. P. Dufour, "Rapidly Measured Indicators of Recreational Water Quality Are Predictive of Swimming-Associated Gastrointestinal Illness,” Environmental Health Perspectives, Vol. 114, No. 1, 2006, pp. 24-28. doi:10.1289/ehp.8273

[16] F. M. Schets, J. F. Schijven and A. M. de R. Husman, "Exposure Assessment for Swimmers in Bathing Waters and Swimming Pools," Water Research, Vol. 45, No. 7, 2008, pp. 2392-2400. doi:10.1016/j.watres.2011.01.025

[17] C. D. McCullough, M. A. Lund and L. Y. L. Zhao, "Mine Voids Management Strategy (I): Pit Lake Resources of the Collie Basin,” Department of Water Project Report MiWER/Centre for Ecosystem Management Report, Edith Cowan University, Perth, 2010, 250 p.

[18] M. A. Lund and C. D. McCullough, "Limnology and Ecology of Low Sulphate, Poorly-Buffered, Acidic Coal Pit Lakes in Collie, Western Australia," Proceedings of the 10th International Mine Water Association, Congress, Karlovy Vary, 2008.

[19] M. A. Lund, D. Bills, T. Keneally, S. Brown and S. Thompson, "Bacterial Strategies for Increasing $\mathrm{pH}$ in Acidic Voids,” Final Void Water Quality Enhancement: Stage III, ACARP Project Number C8031 Report, Perth, 2000, pp. 169-222.

[20] C. Stedman, “100 Years of Collie Coal,” Curtin Printing Services, Perth, 1988.

[21] S. Varma, "Hydrogeology and Groundwater Resources of the Collie Basin, Western Australia,” Hydrogeological Record Series HG 5, Water and Rivers Commission, Perth, 2002, 80 p.

[22] Australian Bureau of Statistics, "National Regional Profile: Collie (S) (Local Government Area),” 2009. http://www.abs.gov.au/AUSSTATS/abs@.nsf/Latestprod ucts/LGA51890Population/People12002-2006?opendocu ment $\&$ tabname $=$ Summary $\&$ prodno $=$ LGA51890\&issue $=2$ 002-2006

[23] NHMRC/NRMMC, “Australian Drinking Water Guidelines 6," National Health and Medical Reseach Council, 2004.

[24] ANZECC/ARMCANZ, "Australian and New Zealand Guidelines for Fresh and Marine Water Quality,” Vol. 1, Australian and New Zealand Environment and Conservation Council and Agriculture and Resource Management Council of Australia and New Zealand, Canberra, 2000.

[25] J. W. Fluhr, R. Darlenski, I. Angelova-Fischer, N. Tsankov and D. Basketter, "Skin irritation and Sensitization: Mechanisms and New Approaches for Risk Assessment," Skin Pharmacology and Physiology, Vol. 21, No. 3, 2008, pp. 124-135. doi:10.1159/000131077

[26] R. P. Mason, J. Laporte and S. Andres, "Factors Controlling the Bioaccumulation of Mercury, Methylmercury, Arsenic, Selenium, and Cadmium by Freshwater Invertebrates and Fish,” Archives Environmental Contamination and Toxicology, Vol. 38, No. 3, 2000, pp. 283-297. doi:10.1007/s002449910038 